\section{Hebrew University of Jerusalem}

The Hebrew University of Jerusalem, now entering on its thirteenth year, is making a special appeal to the Anglo-Jewish community for inereased financial support. A pamphlet issued by its "Friends" (199 Piccadilly, London) gives some account of the University's growth and present status. In grounds covering sixty acres on Mount Scopus, its buildings already include institutes of chemistry, physics, mathematics and meteorology, a library containing more than 300,000 books and an open-air theatre. A hospital and graduates' medical school and nurses' home are under construction, and plans have been prepared for a building for Jewish studies and the humanities. A department of radiology and experimental pathology, at present housed in the Straus Health Centre in Jerusalem, is engaged in cancer research, financed by a special endowment of $£ 40,000$. In a letter, reproduced in the pamphlet, signed by Lord Rutherford, Prof. Albert Einstein, Sir F. Gowland Hopkins, Sir William Bragg and others, it is pointed out that the University is the only one throughout the Near and Middle East in which scientific and scholarly research is a principal activity, and that some of the widely recognized work of its scientific institutes has been of immediate value to the whole population of Palestine. The director of its department of parasitology, engaged in the study of Mediterranean diseases, was chosen by the Royal Society to earry out investigations. Its department of hygiene and bacteriology maintains a malaria research station and has received subventions for its work from the Health Organization of the League of Nations and the Government of Palestine. Jews in the United States contribute nearly half towards the annual budget of $£ 80,000$. Apart from endowments for two chairs and several scholarships, the Jewish community in England has hitherto borne an insignificant part.

\section{Universities of Poland}

Poland's universities are described in a bulletin recently published by the United States Government Printing Office, Washington (pp. 160. 25 cents). It is one of a series of studies undertaken at the request of the American Association of Collegiate Registrars by the Comparative Education Branch of the United States Office of Education. The institutions of higher education in existence in November 1918 within the boundaries of the new State then constituted reflected the influences, German, Austrian and Russian, of the Governments in whose territory they had been located, but have since been brought, along with a larger number of new institutions, into an organized scheme of training on university levels, all under the strict control of the Ministry of Public Instruction. The total number of regular students is 56,000 , being one to 589 of the total population, a high proportion in comparison with those obtaining in other countries. The pressure for admission to many of the institutions such as the polytechnics, academy of mines and the medical schools of the universities, is so great that selection is made by competitive examination from among the qualified candidates. In the small Free Polish University of Warsaw has lately been instituted an ingenious scheme under the name "Universitas Rediviva" for equipping aspirants to a liberal culture with a knowledge of things in general. The name refers to the medieval ideal of a university.

\section{Science in Australia and New Zealand}

The Australian and New Zealand Association for the Advancement of Science is taking steps to give effect to the resolutions passed at the Auckland Meeting last January amending the constitution and by-laws relating to membership. Hitherto, ordinary members have paid a subscription of one guinea for each biennial session of Association; but it has been decided now to institute annual membership (one guinea per annum) and an elected fellowship (two guineas per annum). The fellows resident in Australia will constitute a committee to be known as the Australian National Research Council, which will have at its disposal for research and other purposes a sum not exceeding one half of the subscriptions of fellows and annual members resident in the Commonwealth. The Council will take over all the assets and responsibilities of the existing body of the same name which was brought into being early in the postWar period as the Australian member of the International Research Council. It is anticipated that one of its activities will be the institution of a periodical for the encouragement and dissemination of scientific knowledge among members of the general public.

\section{The Brisbane Seismological Station}

AN important and very welcome addition has recently been made to the chain of Australian seismological stations at Sydney, Melbourne, Adelaide and Perth. As an aid to the study of earthquakes in the south-west Pacific region, a station farther to the north was greatly needed. Interest in the foundation of one in Queensland was aroused by the occurrence of a tremor at Gayndah in April 1935, and a former student in the University of Brisbane offered to provide a Milne-Shaw seismograph. Later, the Council for Scientific and Industrial Research added a second instrument, so that both north-south and east-west components can now be recorded. According to an account given in the Courier-Mail (Brisbane) of June 2, the instruments are installed in the basement of the University's new library block. They were placed temporarily on their foundations about midday on May 31, and at 3.30 the next morning recorded an earthquake with its origin about 1,450 miles from Brisbane. The new station has been placed under the direction of Dr. W. H. Bryan, lecturer in geology in the University.

\section{The American Chemical Society}

THE ninety fourth meeting of the American Chemical Society will be held in Rochester, New York, on September 6-10, under the chairmanship of Mr. M. H. Eisenhart, president of the Bausch and Lomb Optical Co. Seventeen professional divisions of the Society and the Microchemical Section will 